\title{
RATIFIKASI STATUTA ROMA 1998 (ICC) \\ TERHADAP TEGAKNYA KEADILAN DALAM PERLINDUNGAN HAK ASASI MANUSIA DI INDONESIA
}

\author{
Bambang Purwanto
}

\begin{abstract}
In this globalization era, cooperative relationships spread. The relationship between one country and another is as if no border. Problems arousing are also more complicated as the increas-ing of the people's needs. Law has very important roles in regulating those relationships. International law is crucially needed in maintaining harmonious relationships among people and countries. The Rome Statute is more than an international criminal law instrument, but it plays a strategic role in realizing the fulfillment of human rights. The provisions of the Rome Statute are not retroactive. Because the Rome Statute is more oriented to prevent the occurrence of gross human rights violations in the future. When the Rome Statute is ratified, it will improve and strengthen the national legal and human rights system.
\end{abstract}

Keywords : Ratification, Justice, Human Rights

\section{PENDAHULUAN}

Selama setengah abad komunitas internasional telah menciptakan sistem perlindungan terhadap hak asasi manusia secara internasional dan regional, akan tetapi jutaan orang masih terus menjadi korban genosida serta korban kejahatan terhadap kemanusiaan dan kejahatan perang. Secara memalukan, hanya segelintir saja dari mereka yang seharusnya bertanggungjawab terhadap kejahatan ini pernah dibawa ke pengadilan nasional - itu sebabnya kebanyakan pelaku melakukan kejahatan ini dengan pemahaman bahwa mereka sangat tidak mungkin diadili atas tindakan yang mereka lakukan.

Hukum Pidana Internasional telah membuka wawasan baru dalam perkembangan penerapan hukum pidana nasional, tidak ada ancaman kejahatan transnasional dan kejahatan nasional yang

* Bambang Purwanto, Dosen Fakutas Hukum Universitas 17 Agustus 1945 Semarang dapat dihubugi melalui email : bambangpurwanto995 @gmail.com tidak memiliki solusi dan antisipasi.selain itu hukum pidana internasional telah membuka pandangan baru mengenai pertanggungjawaban pidana seorang individu dalam hal kejahatan, Pengadilanpengadilan nasional akan selalu memiliki yurisdiksi terhadap kejahatan-kejahatan semacam itu. Menurut prinsip"saling melengkapi”, International Criminal Court (ICC) hanya akan bertindak ketika pengadilan nasional tidak mampu atau tidak mau melakukannya. Misalnya, sebuah pemerintah mungkin tidak mau menuntut warga negaranya sendiri, khususnya bila mereka mempunyai jabatan Impunitas yang selama ini berlangsung dan dinikmati para pelaku kejahatan HAM akan sirna dihadapan Mahkamah Pidana Internasional. Mahkamah ini, berdasarkan pasal 27 Statuta $I C C$, menganut asas equality before the law dan asas Irelevance Official Capacity. Artinya setiap orang diperlaku kan sama dihadapan hukum dan tidak mengenal kapasitas (jabatan) resmi seorang Indonesia, sebagai negara yang turut serta 
dalam penyusunan Statuta Roma, hingga kini belum meratifikasi Statuta Roma. Padahal, terhitung sejak mulai berlakunya Statuta Roma pada tahun 2002, Indonesia telah menunjukkan komitmennya terhadap Statuta Roma, rencana ratifikasi Statuta Roma sebagai bagian dari peningkatan komitmen Indonesia terhadap HAM.

Organisasi masyarakat sipil yang tergabung dalam koalisi masyarakat sipil Indonesia untuk Mahkamah Pidana Internasional mendesak pemerintah dan DPR untuk segera meratifikasi statuta Roma. ${ }^{1}$ Sayangnya, sampai saat ini Statuta Roma tak kunjung diratifikasi. Padahal, organisasi masyarakat sipil tersebut tidak berdiam diri dan terus mendorong pemerintah untuk segera meratifikasi Statuta Roma. Bahkan, mereka sudah menyiapkan berbagai dokumen yang layak dipertimbangkan pemerintah, salah satunya naskah akademik. Jika Indonesia serius membuktikan kepemimpinannya di ASEAN dan ranah internasional mestinya tidak perlu khawatir untuk meratifikasi Statuta Roma. Apalagi, di tingkat Asia Tenggara, Filipina dan Kamboja sudah lebih dulu meratifikasinya. "Kamboja saja yang tingkat demokrasinya baru dimulai, berani untuk meratifikasi, kenapa Indonesia takut, Adapun inti dari permasalahan yang akan dibahas dalam makalah ini adalah:

1. Masih perlukah Indonesia untuk meratifikasi Statuta Roma 1998 (ICC)?

2. Apakah dengan tidak meratifikasi Statuta Roma 1998 akan terlepas dari peradilan ICC?

\section{PEMBAHASAN}

1. Perlunya Indonesia untuk meratifikasi Statuta Roma 1998 (ICC)

Pada bulan Juli 1998 masyarakat internasional mencatat suatu peletakan instumen hukum dalam rangka pembentuk an lembaga internasional yang sangat penting, yaitu dengan berdirinya

1 http://www.hukumonline.com/berita/baca/1t51e6c2ca4
Mahkamah Pidana Internasional, melalui Rome Statute of The International Criminal Court1998. Suatu lembaga yang sifatnya berbeda dengan mahkamah / pengadilan pengadilan ad hoc sebelumnya, Mahkamah Pidana Internasional ini bersifat permanen. ${ }^{2}$

Statuta Roma adalah perjanjian yang diadopsi dalam Konferensi Roma 1998 untuk menjadi dasar terbentuknya International Criminal Court (selanjutnya disebut ICC) Pengadilan Pidana Internasional merupakan sebuah lembaga yudisial independen yang permanen, yang diciptakan oleh komunitas negara-negara internasional, untuk mengusut kejahatan yang mungkin dianggap sebagai yang terbesar menurut hukum internasional seperti: genosida (salah satu kejahatan pelanggaran HAM berskala internasional yang penanganannya juga harus dilakukan oleh pihak Internasional), dan kejahatan lain terhadap kemanusiaan dan kejahatan perang.

Statuta Romaini disahkan pada tanggal 17 Juli 1998. Sebanyak 120 negara, tujuh (7) negara menolak (Amerika Serikat, China, Irak, Israel, Yaman, Qatar, Libya), dan 21 negara lainnya abstain. Untuk berlakunya statuta ini dibutuhkan 60 ratifikasi dari negara peserta. Syarat tersebut terpenuhi pada tanggal 11 April 2002 karena pada tanggal tersebut sebanyak 66 negara telah meratifikasi statuta tersebut. Oleh karenanya ICC mulai bekerja sejak 11 Juli 2002. Maka sejak saat itulah ICC resmi berdiri dan hadir melengkapi sistem hukum internasional.

Terkait ICC, Statuta Roma mengaturnya di bagian 1. Pasal 1 mendefinisikan ICC sebagai "permanent institution andshall have the power to exercise its jurisdiction over persons for the most serious crimes of international concern, as referred to in this Statute, and shall be complementary to national

2 Arlina Permanasari, dkk., 2005, Pengantar Hukum Humaniter, International Committee of Red Cross, Jakarta, hlm. 190-191. 
criminal jurisdictions. Dialihbahasakan oleh ELSAM, mahkamah tersebut merupakan "suatu lembaga permanen dan mempunyai kekuasaan untuk melaksana kan jurisdiksinya atas orang-orang untuk kejahatan paling serius yang menjadi perhatian internasional, sebagaimana dicantumkan dalam Statuta ini, dan merupakan pelengkap terhadap jurisdiksi kejahatan nasional". Kejahatan-kejahatan tersebut adalah genosida, kejahatan kemanusiaan, kejahatan perang, dan kejahatan agresi $^{3}$

Mahkamah Pidana Internasional (International Criminal Court/ICC) memiliki yurisdiksi atas kejahatan yang ditentukan dalam Pasal 5 ayat 1 Statuta Roma 1998, yang redaksi lengkapnya sebagai berikut: The jurisdiction of the Court shall be limited to the most serious crimes of concern to the international community as a whole. The Court has jurisdiction in accordance with this Statute with respect to the following crimes:

(a) The crime of genocide (Kejahatan genosida);

(b) Crimes against humanity(Kejahatan Kemanusiaan),

(c) War crimes(Kejahatan Perang); dan

(d) The crime of aggression (Kejahatan Agresi). ${ }^{4}$

Statuta Roma 1998 juga menentu kan bahwa Mahkamah Pidana Internasional memiliki asas-asas antara lain sebagai berikut:

a. Prinsip Komplementer

Tercantum secara tegas dalam Mukadimah Statuta Roma tentang Mahkamah Pidana Internasional 1998, bahwa Statuta ini hanya sebagai pelengkap yurisdiksi pidana hukum nasional. Pasal 1 Statuta Roma 1998 merupakan penegasan

3 Elsam 2014, "UU Nomor 26 Tahun 2000 Tentang Pengadilan Hak Asasi Manusia", 30 September 2014, elsam.or.id, $<$ http:// referensi.elsam.or.id/2014/09/uu-nomor-26tahun-2000-tentang-pengadilan-hak-asasimanusia

4 Article Rome Statute of The International Criminal Court 1998. bahwa adanya statuta tidak semata-mata menggantikan sistem pidana nasional yang ada. Hal ini sebagai perwujudan penghargaan terhadap kedaulatan Negara dan pengharapan masyarakat internasional untuk ikut membantu mendorong pembentukan dan penerapan sistem hukum pidana nasional terhadap kejahatankejahatan yang menjadi perhatian dunia ${ }^{5}$

b. Prinsip Penerimaan

Prinsip ini menunjukkan bahwa statuta merujuk kepada hubungan komplek antara sistem hukum nasional dengan Mahkamah Pidana Internasional. Mahkamah Pidana Internasional tidak dapat menerima jika dalam keadaan:

1) Sedang dilaksanakannya sistem hukum nasional untuk memeriksa dan mengadili oleh negara setempat, kecuali negara tersebut dianggap unable atau unwilling.

2) Telah dilaksanakannya penyelidikan oleh negara setempat dan negara setempat tidak berkehendak untuk mengajukan tuntutan terhadap individu yang bersangkutan, kecuali disebabkan oleh faktor ketidaksediaan atau ketidakmauan negara.

3) Individu yang bersangkutan telah dipidana atas dasar tindakan sama yang menjadi dasar tuntutan dari Mahkamah Pidana Internasional.

4) Tindak pidana yang ringan untuk ditangani Mahkamah Pidana Inter nasional.

Ketentuan-ketentuan di atas semata mata untuk mengurangi bahkan menghapus konsep immunitas individu.

c. Prinsip Otomatis

Statuta secara otomatis akan ber laku jika terjadi pelanggaran terhadap ketentuan atau tindak pidana yang tercantum dalam statuta, tanpa harus menunggu persetujuan dari negara pihak. Mahkamah pidana internasional dapat

5 Boer Mauna, 2005, Hukum Internasional; Pengantar Peranan dan Fungsi dalam EraDinamika Global, Edisi kedua, Alumni, Bandung, hlm. 297. 
menerapkan yurisdiksinya apabila:

1) Kejahatan tersebut terjadi di negara pihak;

2) Pelaku kejahatan berasal dari negara pihak.

Bagi negara yang bukan anggota atau pihak dari statuta, baginya dapat berlaku yurisdiksi Mahkamah Pidana Internasional melalui pernyataan penerima an yurisdiksi oleh negara non pihak statuta untuk kasus per kasus

d. Ratione Temporis (yurisdiksi temporal) Mahkamah Pidana Internasional merupakan lembaga yang prospektif, sehingga terhadap para pihak dalam lembaga ini tidak berlaku asas retroaktif terhadap tindakan-tindakan kejahatan yang lampau. Jadi mahkamah hanya memiliki yurisdiksi terhadap tindak kejahatan yang terjadi setelah negara pihak meratifikasi dan tanggal aktif dari statuta ${ }^{6}$

e. Menurut prinsipsaling melengkapi

ICC hanya akan bertindak ketika pengadilan nasional tidak mampu atau tidak mau melakukannya. Misalnya, sebuah pemerintah mungkin tidak mau menuntut warga negaranya sendiri, khususnya bila mereka mempunyai jabatan tinggi, atau jika sistem pengadilan pidana tidak berfungsi akibat konflik internal, yang kemudian mungkin tidak ada pengadilan yang mampu mengatasi kejahatankejahatan sejenis ini.

Pengadilan tersebut memiliki yurisdiksi untuk menuntut para individu ketika:

a. Kejahatan dilakukan di wilayah negara yang telah meratifikasi Statuta Roma;

b. Kejahatan dilakukan oleh warga negara dari sebuah negara yang telah meratifikasi Statuta Roma;

c. Negara yang belum meratifikasi Statuta Roma tetapi telah membuat deklarasi yang menyetujui yurisdiksi pengadilan terhadap tindak kejahatan;

d. Kejahatan dilakukan dalam situasi yang mengancam perdamaian dan

6 Idem.,hlm. 297-298 keamanan internasional dan Dewan Keamanan PBB sudah mengajukan situasi tersebut ke muka Pengadilan berdasarkanbab 7 Piagam PBB

Otto Triffterer, mengemukakan bahwa: "Hukum Pidana Internasional termasuk sejumlah ketentuan internasional yang menetapkan suatu perbuatan merupakan kejahatan menurut hukum internasional".?

Terkait dengan definisi Otto tersebut diatas maka dapat dikatakan bahwa, keberadaan hukum pidana internasional, lebih tepat dikatakan, "The bridging science"yang menghubungkan dua kepentingan, yaitu: kepentingan (hukum) internasional (International Interest) dan kepentingan (hukum) nasional (National Interest) dalam menghadapi satu objek yang sama yaitu ancaman dari kejahatan transnasional dan kejahatan internasional, kedua kepentingan tersebut merupakan "Pasangan Harmonis" dalam praktik penegakan hukum pidana inter nasional.

Tujuan pembentukan ICC adalah menghentikan praktek impunity dan pelaku (perpetrator) tidak dapat berlindung dibalik ketentuan nasional karena pelaku pelanggaran HAM berat menyandang status pariah yaitu musuh umat manusia (hostis humanis generis). Karenanya kewajiban dari masyarakat internasional untuk melakukan penangkapan, penahanan, ekstradisi dan peradilan terhadap para pelakunya tanpa memandang kewarganegaraannya. Ini diatur di dalam Principles of international co-operation in the detection, arrest, extradition and punishment of persons guilty of war crimes and crimes agains humanity yang diadopsi oleh melalui Resolusi Majelis Umum PBB (XXVIII) tanggal 3 Desember 1973.

Dalam Statuta Roma menekankan kaidah untuk mengadili kejahatan serius, memutuskan rantai kekebalan hukum, dan

7 http//www.blogger com/blogegger.9blog id.5057770398291433208 
menghormati kedaulatan dan yurisdiksi nasional. Kaidah-kaidah tersebut kemudian dituangkan dalam berbagai pasal Statuta Roma. Sehingga, kaidah-kaidah tersebut adalah pondasi fundamental bagi keberlangsungan Statuta Roma sebagai kesepakatan internasional untuk pengadil an pidana internasional.

Tujuan pembentukan ICC adalah menghentikan praktek impunity dan pelaku (perpetrator) tidak dapat berlindung dibalik ketentuan nasional karena pelaku pelanggaran HAM berat menyandang status pariah yaitu musuh umat manusia (hostis humanis generis). Karenanya kewajiban dari masyarakat internasional untuk melakukan penangkapan, penahanan, ekstradisi dan peradilan terhadap para pelakunya tanpa memandang kewarganegaraannya. Ini diatur di dalam Principles of international co-operation in the detection, arrest, extradition and punishment of persons guilty of war crimes and crimes agains humanity yang diadopsi oleh melalui Resolusi Majelis Umum PBB (XXVIII) tanggal 3 Desember 1973.

Secara garis besar Indonesia menempatkan norma penghormatan HAM sebagai dasar dari komitmen pengadilan kejahatan berat dalam Pancasila dan UUD 1945. Sebagai dua sumber hukum tertinggi, kaidah tersebut kemudian dituangkan dalam berbagai undang-undang, misalnya UU nomor 26 tahun 2000. Secara praktis, komitmen tersebut dilaksanakan melalui langkah-langkah seperti pembentukan pengadilan HAM. Komitmen Indonesia dalam perlindungan Hak Asasi Manusia telah diamanatkan dari dasar negaranya. HAM telah dilindungi oleh Pancasila melalui sila keduanya yaitu Kemanusiaan yang Adil dan Beradab. Sila ini adalah sintesis dari dua kata yaitu adil yang berarti suatu keputusan dan tindakan didasarkan atas norma-norma yang objektif dan tidak otoriter serta beradab yang berarti kesadaran manusia dalam hubungan dengan norma-norma. ${ }^{8}$ Melalui sila ini,
NKRI mendeklarasikan dirinya sebagai negara yang menjunjung tinggi Hak Asasi Manusia melalui hukum yang adil dan negara berbudaya yang beradab.

Statuta Roma dalam mukadimah nya juga senada dalam hal ini dengan mengingatkan bahwa merupakan kewajib an setiap negara untuk melaksanakan yurisdiksi pidananya terhadap orang-orang yang bertanggung jawab atas kejahatan internasional. Pelaksanaan yurisdiksi tersebut adalah pengejawantahan dari perlindungan dari kesewenangan kekuasa an yang disinggung sebelumnya. Empat kejahatan yang diatur dalam Statuta Roma tidak bisa dilakukan tanpa komando dari penguasa, terbukti dari mereka yang diadili oleh ICC kesemuanya adalah pemegang kekuasaan tertinggi dari suatu negara. Sementara itu, Elsam juga senada dengan berpendapat bahwa "norma kita sesuai. Misalnya dalam konstitusi kita ada kewajiban negara untuk melindungi HAM...termasuk menegaskan kewajiban penghormatan dan perlindungannya".

Secara faktual dalam penanganan kejahatan HAM berat, Indonesia telah memiliki payung hukumnya sendiri dalam UU nomor 26 tahun 2000 sebagai pengejawantahan penghormatan HAM yang dijelaskan sebelumnya. Secara historis UU ini lahir karena amanat Bab IX Pasal 104 Ayat (1) UU No. 39 Tahun 1999. ${ }^{10}$ UU yang kemudian memberikan terobosan berupa penyelesaian kasus HAM di peradilan umum ini adalah salah satu bentuk kepedulian negara terhadap hak asasi warganya. Tidak hanya itu, negara juga menyadari perlunya sebuah lembaga untuk menjamin hak pribadi seseorang

8 Suparman, M 2011, Tragedi Politik Hukum HAM, Yogyakarta, Pustaka Pelajar. UndangUndang Dasar Negara Republik Indonesia Tahun 1945 Amandemen ke-IV,

9 Kebijakan Indonesia Belum Meratifikasi Statuta Roma 1998 Journal of International Relations, Volume 3, Nomor 2, Tahun 2017

10 Elsam 2014, "UU Nomor 26 Tahun 2000 Tentang Pengadilan Hak Asasi Manusia", 30 September 2014, elsam.or. id, 
sehingga setiap individu bisa mengetahui batas haknya dan menjamin hak orang lain.

Tidak hanya amanat perlindungan terhadap warganya, Pancasila dan UUD 1945 juga mengamanatkan keikutsertaan Indonesia dalam ketertiban dunia yang termuat dalam Pancasila sila kedua sebagai orientasi kemanusiaan ke luar dan pada pembukaan melalui kalimat "ikut melaksanakan ketertiban dunia yang berdasarkan kemerdekaan, perdamaian abadi dan keadilan sosial ". Komitmen yang menjadi dasar pelaksanaan hubungan internasional Indonesia tersebut sejalan dengan prinsip ICC. Kejahatan pidana internasional, sebagai yurisdiksi ICC, diakui secara tegas sebagai "mengancam perdamaian, keamanan dan kesejahteraan dunia”. Dengan terlibat penegakan norma Statuta Roma, maka Indonesia juga turut serta dalam penegakan ketertiban dunia sebagai tujuan negara yang diamanatkan dalam konsititusi.

Terkait dengan waktu (Yurisdiksi Ratione Temporis) terdapat kesesuaian antara Statuta ICC dengan UUD.Dari mahkamah ini terbatas pada kajahatankejahatan sebagaimana dimaksud pasal 5 statuta ini yang terjadinya setelah tanggal berlakunya statuta ini yaitu 11 Juli 2002. Hal ini diatur dalam pasal 11. Yurisdiksi mengenai waktu terjadinya kejahatan ini menegaskan pula asas non retro aktif yang dianut oleh mahkamah, artinya kejahatan yang dilakukan sebelum tanggal 11 Juli 2002 bukan menjadi wewenang mahkamah. Jika dikaitkan dengan bunyi pasal 28 I UUD 1945 yang berbunyi “ Hak untuk tidak dituntut atas dasar hukum yang berlaku surut," maka terdapat kesesuaian antara Statuta ICC dengan UUD.

Indonesia telah memiliki sejarah panjang terkait komitmen terhadap Statuta Roma, baik secara eksplisit maupun implisit. Pemerintahan Megawati memiliki komitmen yang paling eksplisit ${ }^{11}$ bahwa

\footnotetext{
$11 \mathrm{http} / /$ advokasi.elsam.or.id/assets/2015/09/ 2008_Kertas-Kerja_Indonesia-menujuratifikasi-statuta-roma.pdf
}

sumbangan penting pemerintahan Megawati adalah lahirnya produk-produk hukum yang maju dalam berbagai hal dan termasuk di antaranya adalah penguatan hak sipil dan politik. Salah satunya adalah komitmen untuk meratifikasi Statuta Roma yang tercantum dengan jelas di RAN HAM 2004-2009 yang diundangkan dalam Perpres nomor 40 tahun 2004. Statuta Roma dipandang sebagai salah satu perjanjian internasional yang penting dalam pemajuan HAM di Indonesia.

Semasa Pemerintahan SBY Indonesia sering didesak oleh negaranegara Eropa, termasuk Belanda, untuk meratifikasi. Desakan tersebut kemudian berbuah hasil ketika Presiden SBY mengajukan RUU Pengesahan Statuta Roma ke DPR. Sayangnya, hasil tersebut disebit Hikmahanto yang menuding bahwa rencana ratifikasi tersebut adalah buah desakan Eropa kepada Indonesia,"Bila akhirnya tahun ini Indonesia meratifikasi maka akan muncul kesan Indonesia tunduk pada desakan luar negeri. Kedaulatan Indonesia seolah mudah dirongrong," jelasnya."Kalaulah Indonesia hendak meratifikasi Statuta Roma hendaknya ditentukan oleh Indonesia sendiri tanpa desakan negara lain.Indonesia juga seharusnya tidak terkesima seolah dengan meratifikasi Statuta Roma maka kejahatan internasional tidak akan ada lagi." ${ }^{12}$

Sementara itu, pemerintahan Jokowi memiliki komitmen yang implisit. Komitmen tersebut dituangkan dalam Simposium 1965 yang lahir dari ketidakpuasan akan tidak tuntasnya penyelesaian tragedi 1965 selama setengah abad. Komitmen Jokowi juga ditegaskan dengan pengakuan beliau sendiri bahwa masalah HAM masih banyak yang belum bisa diselesaikan. Hal tersebut dapat dimaklumi karena penyelesaian masalah HAM adalah sebuah proses panjang dan pada saat ini Jokowi masih menyelesaikan

12 https://news.detik.com/berita/d-2189116/indonesia-belum-tepat-ratifikasi-statuta-roma 
prioritas awal pemerintahannya yaitu pembangunan infrastruktur, deregulasi, dan kesejahteraan rakyat. ${ }^{13}$

Komitmen-komitmen tersebut sejalan dengan norma domestik Indonesia dalam pengakuan HAM oleh konstitusi tercantum pada UUD 1945 sebagai konstitusi RI yang memberikan jaminan perlindungan HAM. Sebagaimana telah ditulis di atas, dimuatnya bab dan pasal tentang HAM tersebut berarti bahwa negara mengakui dan menghormati bahwa hakhak asasi manusia bukanlah pemberian negara tetapi melekat (inherent) dalam keberadaan manusia. Pengakuan ini memberikan konsekuensi bagi negara untuk menerapkan prinsip rule of law, yang didefinisikan sebagai perlindungan warga negara dari kesewenangan kekuasaan dan melindungi warga dan hak-miliknya dari kesewenangan sesama warga.

Wakil Koordinator untuk Orang Hilang dan Korban Tindak Kekerasan (Kontras) Puri Kencana Putri mengatakan, dengan mengadopsi Statuta Roma, maka Indonesia akan terikat pada agenda akuntabilitas keadilan global. "Jika pemerintah meratifikasi Statuta Roma, maka harus ada komitmen untuk memperbaiki kualitas access to justice dari ranah penegakan hukum, penuntutan, peradilan, hingga mereformasi peradilan militer yang tidak tersentuh oleh konsep akuntabilitas hukum pidana internasional," ujar Puri, saat dihubungi Kompas.com, Jumat (19/5/2017). Puri menyebutkan, tujuan dari pembentukan Statuta Roma adalah untuk menjamin hadirnya aspek keadilan bagi korban. Sistem pengadilan pidana internasional (International Criminal Court) yang diatur dalam Statuta Roma, mensyaratkan agar sistem hukum pidana di tingkat nasional dapat bekerja efektif dalam menghadirkan keadilan melalui jalur yudisial. ${ }^{14}$

13 Waluyo, A 2015 'Presiden Pastikan Komitmen Penegakan HAM di Tanah air', 11 Desember, VOAIndonesia
Menurut anggota koalisi masyarakat sipil Indonesia yang juga Direktur Eksekutif Elsam, Indriaswati Dyah Saptaningrum, juga menyoroti dalih pihak tertentu yang menyebut Statuta Roma sebaiknya diratifikasi setelah sistem hukum di Indonesia diperbaiki. Baginya, pernyataan itu tidak beralasan karena pemerintah tidak punya target kapan reformasi hukum diselesaikan. Untuk meratifikasi KUHP saja Indri melihat butuh waktu puluhan tahun dan sampai sekarang masih berlarut. ${ }^{15}$

Sedangkan Elsam memandang bahwa Indonesia masih belum memiliki politicalwill untuk perjanjian internasional yang memiliki sensitivitas tinggi. Dikatakan bahwa"Political will, apapun perjanjian internasional yang memiliki sensitivitas tinggi akan sulit untuk masuk. Belum adanya political will terhadap perjanjian yang memiliki tingkat sensitivitias tinggi merupakan hasil dari belum jelasnya sikap Indonesia terhadap posisi hukum domestik dan internasional. Ketidakjelasan sikap ini ditegaskan oleh Elsam bahwa "posisi Indonesia itu cenderung abu-abu, walaupun ada paham monisme (hukum internasional dan domestik sebagai satu kesatuan) dan dualisme (hukum internasional dan domestik sebagai dua hal yang berbeda), Indonesia tidak memiliki pilihan tegas atas kedua prinsip tersebut.

Ketidakjelasan sikap tersebut dapat terjadi karena aturan yang menegaskan terkait kedudukan perjanjian internasional dalam sistem hukum nasional sangat minim dan kontradiktif. Contohnya, UU No/ 24 tahun 2000 tentang Perjanjian Internasional hanya menjelaskan bahwa perjanjian internasional berlaku jika telah disahkan oleh UU tanpa menjelaskan bagaimana hubungan antara hukum nasional dan

$14 \mathrm{https}: / /$ nasional.kompas.com/read/2017/ 05/19/14045221/pemerintah.diharapkan.ratifik asi.statuta.roma.

15 http://www.hukumonline.com/berita/baca/ $1 \mathrm{t} 51 \mathrm{e} 6 \mathrm{c} 2 \mathrm{ca} 4$ 
internasional, ${ }^{16}$ sedangkan UU nomor 10 tahun 2004 justru memberi persepsi bahwa perjanjian internasional satu dengan yang lain bergantung pada instrumen hukum nasional. Untuk itu kita perlu mendorong dan mendesak Pemerintah Indonesia untuk secara aktif menempatkan diri sebagai bagian dari negara-negara beradab yang mendukung diselenggarakannya ICC melalui ratifikasi/aksesi terhadap Rome Statute of International Criminal Court, karna ICC mampu berkontribusi terhadap perdamaian internasional dengan memastikan bahwa kejahatan yang paling berat sekalipun tidak akan lepas dari jerat hukum dan mempromosikan penghormatan kepada hukum internasional. Selain norma anti impunitas tersebut, Statuta Roma juga memiliki norma penghormatan terhadap kedaulatan. Norma ini kemudian dituang kan melalui asas komplementer. Dengan asas ini, Statuta Roma bersifat melengkapi yurisdiksi pidana nasional dan hanya bisa melaksanakan mandatnya apabila suatu negara dianggap tidak mau atau tidak mampu mengadili pelaku kejahatan berat.

\section{Tidak meratifikasi Statuta Roma 1998 bukan berarti terlepas dari mekanisme peradilan ICC.}

Direktur FRR Law Office sekaligus pakar hukum humaniter internasional, Fadillah Agus mengingatkan, sekalipun Indonesia tidak meratifikasi Statuta Roma, bukan berarti bisa lepas dari mekanisme peradilan ICC. Pasalnya, jika ke depan terjadi pelanggaran HAM berat, besar kemungkinan Indonesia dapat diseret ke ICC. Menurutnya, hal itu pernah dialami pemerintah di Sudan. ${ }^{17}$

Mahkamah dalam melaksanakan yurisdiksinya tidak perlu mempertimbang kan apakah negara itu mengakui dan telah meratifikasi Statuta ICC, melainkan

\footnotetext{
16 Sefriani 2016, Peran Hukum Internasional dalam Hubungan Internasional Kontemporer, Jakarta:Raja Grafindo Persada, hal 118-119

17 http://www.hukumonline.com/berita/baca/ lt5 1 e6c $2 \mathrm{ca} 4$
}

mahkamah mempunyai wewenang untuk mengadili kasus yang terjadi di negara itu atau mengadili warganegaranya, tidak peduli negara itu negara peratifikasi statuta atau bukan, asalkan usul penuntutan itu berasal dari resolusi DK PBB.

Berdasarkan ketentuan diatas, sebenarnya yurisdiksi Mahkamah Pidana Internasional berlaku untuk semua wilayah teritorial negara dan berlaku juga untuk semua warganegara dari negara manapun. Tetapi memang yang belakangan ini harus melalui usul investigasi / penyelidikan / penuntutan dari DK PBB. Hal ini menarik untuk disimak, mengingat disatu sisi mahkamah mempunyai yurisdiksi relatif (hanya kepada negara peratifikasi atau penerima Statuta ICC) namun disisi lain mahkamah memliki yurisdiksi absolut (ketika DK PBB mengusulkan suatu kasus untuk ditangani.

Ketentuan menganai kewenangan mengadili dari mahkamah ini tentu tetap mengacu pada pasal 17 Statuta ini. Ketentuan mana menegaskan bahwa mahkamah hanya dapat bertindak setelah pengadilan nasional tidak mau atau tidak mampu untuk mengadili. Secara in concreto, jika terjadi suatu kejahatan yang masuk dalam yurisdiksi mahkamah, maka kejahatan tersebut akan dianalisis apakah terjadi di negara peratifikasi ? dan jika terjadi di negara yang tidak meratifikasi, apakah kejahatan itu telah diusulkan oleh DK PBB kepada mahkamah untuk diadili ? setelah semua analisis telah dilakukan dan hasilnya menunjukan bahwa kejahatan itu masuk dalam yurisdiksi mahkamah, mahkamah tidak dapat secara langsung melakukan proses hukum terhadap tertuduh, melainkan harus mengkoordinasi kan dengan negara yang bersangkutan untuk melakukan penuntutan. Setelah hal itu disampaikan kepada negara yang bersangkutan dan negara tersebut ternyata tidak mau atau tidak mampu melaksanakan pengadilan terhadap pelaku kejahatan, barulah Mahkamah Pidana Internasional 
yang akan mengadilinya.

Inilah yang dinamakan fungsi komplementer dari Mahkamah Pidana Internasional, melengkapi pengadilan nasional. Hak pertama untuk melakukan penuntutan dan pengadilan terhadap kejahatan tetap dimiliki negara yang bersangkutan. Namun apabila ditemukan unsur Unwiling dan Inability untuk melaksanakan penuntutan terhadap pelaku kejahatan, barulah Mahkamah Pidana Internasional yang akan mengadili. Hal ini membuktikan bahwa Mahkamah Pidana Internasional berkedudukan sebagai the last of the last resort, bukan the first resort. Sistem yang saling melengkapi dan saling menyokong inilah yang diharapkan akan menghentikan praktek impunitas (lepas / bebas dari hukuman) yang selama ini dinikmati oleh pelaku kejahatan.

Ratifikasi ICC akan memiliki manfaat yang luar biasa besar, antara lain :

a. Ratifikasi akan menjadi cambuk bagi pemerintah untuk meralisasikan komitmen dan ucapannya dalam penegakan HAM dan keadilan. Ratifikasi oleh Indonesia akan dijadikan ukuran masyarakat atas keseriusan pemerintah saat ini yang cenderung hanya merealisasikan keadilan formal, dalam tataran tulisan dan ucapan.

b. Ratifikasi atas ICC akan berdampak pada penguatan dan perbaikan mekanisme pengadilan hak asasi manusia yang saat ini sedang kolaps. Ratifikasi ICC akan menjadikan dasar yang kuat bagi perlunya melakukan amandemen mendasar atas peraturan perundangan tentang hak asasi manusia, terutama UU No 26 tahun 2000 tentang Pengadilan HAM yang selama ini tidak efektif dan tidak memenuhi standar fair trial inte rnasional. Ratifikasi atas Statuta Roma yang dibarengi dengan perbaikan atas perundangan mengenai HAM dan Pengadilan HAM akan bisa memberi salah satu terobosan atas kebuntuan penanganan kasus-kasus pelanggaran berat HAM. Sebagaimana terlihat dalam implementasi UU No 26 tahun 2000 melalui proses Pengadilan HAM Tanjung Priok, Timor Timur dan Abepura serta proses penyelidikan dan penyidikan dugaan pelanggaran berat HAM lainnya (kasus Mei 98, Trisakti Semanggi I dan II, Penghilangan Paksa dl1), UU No 26 tahun 2000 terlihat mandul dan kelemahannya sering dimanfaatkan oleh para pelaku pelanggaran HAM. Hal ini terjadi terutama karena UU No 26 tahun 2000 tidak mengadopsi KUHP (rules of procedures) dan unsur-unsur pidana (elemets of crimes) ICC yang ada pada Statuta Roma. ${ }^{18}$

c. Ratifikasi ICC oleh Indonesia pada saat ini akan menjadikan Indonesia memiliki akses untuk berpartisipasi dalam berbagai proses dan operasional ICC yang berkedudukan di Den Hague ini semisal dalam pencalonan hakim, penuntut, Victim Trust Fund, dan badan-badan ICC yang lain. Indonesia juga bisa memberikan berpartisipasi secara maksimal dalam memberikan masukan tentang perubahan-perubahan mendasar yang mungkin dilakukan terhadap ICC.

d. Ratifikasi atas ICC oleh Indonesia akan memiliki keuntungan-keuntungan Selain ikut mendorong penegakan hukum bagi pelaku kejahatan internasional, Indonesia juga memiliki kesempatan untuk memberdayakan para pakar hukum di Indonesia untuk ikut terlibat dalam penanganan pengadilan ini, sehingga memiliki pengalaman dalam penanganan hukum internasional. "Banyak orang Indonesia yang mampu.

Dari itu semua, percepatan ratifikasi ICC oleh Indonesia akan menjadikan

18 http://mugiyanto.blogspot.co.id/2007/07/ indonesia-segera-ratifikasi-icc.html 
Indonesia bisa berdiri sama tinggi dengan negara-negara lain dalam komitmen yang sama dalam mewujudkan keadilan global.

\section{KESIMPULAN}

Statuta Roma lebih dari instrumen hukum pidana internasional semata, tapi berperan strategis untuk mewujudkan pemenuhan HAM. Ketentuan yang ada dalam Statuta Roma tidak berlaku surut. Pasalnya, Statuta Roma lebih berorientasi untuk mencegah terjadinya pelanggaran HAM berat di masa depan. Jika Statuta Roma diratifikasi, akan memperbaiki dan memperkuat sistem hukum dan HAM nasional.

Tidak ada benturan norma yang terjadi antara Statuta Roma dan hukum domestik Indonesia. Oleh karena itu, pemerintah seharusnya tidak lagi memiliki keraguan untuk meratifikasi Statuta Roma, dengan meratifikasi Statuta Roma, Indonesia berarti telah melaksanakan amanat untuk ikut serta dalam ketertiban dunia dan perlindungan Hak Asasi Manusia sebagaimana diamanatkan oleh konstitusi Indonesia.

Dalam melaksanakan yurisdiksinya ICC tidak perlu mempertimbangkan apakah negara itu mengakui dan telah meratifikasi Statuta ICC, melainkan mahkamah mempunyai wewenang untuk mengadili kasus yang terjadi di negara itu atau mengadili warganegaranya, tidak peduli negara itu negara peratifikasi statuta atau bukan, asalkan usul penuntutan itu berasal dari resolusi DK PBB.

\section{DAFTAR PUSTAKA}

Arlina Permanasari, dkk., 2005, Pengantar Hukum Humaniter, International

Committee of Red Cross, Jakarta, hlm. 190191.

Boer Mauna, 2005, Hukum Internasional; Pengantar Peranan dan Fungsi dalam EraDinamika Global, Edisi kedua, Alumni, Bandung, hlm. 297.
Pratomo, Eddy 2016, Hukum Perjanjian Internasional, Grasindo:Jakarta, hal 565

Sefriani 2016, Peran Hukum Internasional dalam Hubungan Internasional

Kontemporer, Jakarta:Raja Grafindo Persada, hal 118-119

Waluyo, A 2015 'Presiden Pastikan Komitmen Penegakan HAM di Tanah air' 11 Desember, VOA Indonesia, Wakhid Aprizal Maruf Kebijakan Indonesia Belum Meratifikasi Statuta Roma 1998 Journal of International Relations, Volume 3, Nomor 2, Tahun 2017

Elsam 2014, "UU Nomor 26 Tahun 2000 Tentang Pengadilan Hak Asasi Manusia", 30 September 2014 Rome Statute of the International Criminal Court, ditandatangani pada 17 Juli 1998, U.N. Doc. A/CONF.183/9*, efektif 1 Juli 2002

Badan Pembinaan Hukum Nasional 2015, Draft Naskah Akademik Rancangan Undang-Undang Tentang Kitab Undang-Undang Hukum Pidana (KUHP), KementerianHukum dan HAM RI:Jakarta

http://www.hukumonline.com/berita/baca/ $1 t 51$ e6c2ca4

http://referensi.elsam.or.id/2014/09/uunomor-26-tahun-2000-tentangpengadilan-hak-asasi-manusia

http://mugiyanto.blogspot.co.id/2007/07/i ndonesia-segera-ratifikasi-icc.html

http://referensi.elsam.or.id/2014/09/uunomor-26-tahun-2000-tentangpengadilan-hak-asasi-manusia

Article Rome Statute of The International Criminal Court 1998.

http//www.blogger com/blogegger.9blog id. 5057770398291433208

http://advokasi.elsam.or.id/assets/2015/09/ 2008_Kertas-Kerja_Indonesiamenuju-ratifikasi-statuta-roma.pdf

https://news.detik.com/berita/d-2189116/indonesia-belum-tepat-ratifikasistatuta-roma 
Bambang Purwanto : Ratifikasi Statuta Roma 1998 (ICC) Terhadap Tegaknya Keadilan ......

https://nasional.tempo.co/read/789593/pre siden-jokowi-diminta-tuntaskantragedi-1965

https://nasional.kompas.com/read/2017/05 /19/14045221/pemerintah.diharapk an.ratifikasi.statuta.roma. http://www.hukumonline.com/berit a/baca/lt51e6c2ca4
Laporan Sekretaris Jenderal PBB, ditandatangani pada 23 Agustus 2004, S/2004/616, paragraf 49 